\title{
Pengaruh Pelatihan Kerja dan Penilaian Kinerja Terhadap Kinerja Karyawan Direktorat Umum dan SDM BPJS Ketenagakerjaan Pusat
}

\author{
Gita Maharani ${ }^{1}$, Syarif Ali $^{2}$, Zackharia Rialmi ${ }^{3}$ \\ ${ }^{123}$ Universitas Pembangunan Nasional Veteran Jakarta
}

\begin{abstract}
This study uses quantitative methods in order to determine and prove the effect of job training and performance appraisals on employee performance. The sample used were employees of the Direktorat Umum dan SDM, amounting to 100 employees. The method for collecting data uses a questionnaire via google form. Using inferential analysis techniques and data processing was carried out through SPSS Statistics 23 with a significant level of 0.05. The conclusions of this research are (1) job training has an effect on employee performance, (2) performance appraisal has an effect on employee performance, (3) job training and performance appraisal simultaneously have an effect on employee performance.
\end{abstract}

Keywords: job training, performance appraisal, and employee performance.

\begin{abstract}
Abstrak
Penelitian menggunakan metode kuantitatif dengan tujuan untuk mengetahui dan membuktikan pengaruh pelatihan kerja dan penilaian kinerja terhadap kinerja karyawan. Sampel penelitian yaitu seluruh karyawan Direktorat Umum dan SDM berjumlah 100 karyawan. Metode untuk mengumpulkan data menggunakan kuesioner melalui google form. Menggunakan teknik analisis inferensial dan pengolahan data dilakukan melalui SPSS Statistics 23 dengan tingkat signifikan 0,05. Simpulan penelitian yaitu (1) pelatihan kerja berpengaruh terhadap kinerja karyawan, (2) penilaian kinerja berpengaruh terhadap kinerja karyawan, (3) pelatihan kerja dan penilaian kinerja secara simultan berpengaruh terhadap kinerja karyawan.
\end{abstract}

Kata kunci: pelatihan kerja, penilaian kinerja, dan kinerja karyawan.

\begin{tabular}{lcl}
\hline Permalink/DOI & $:$ & http://dx.doi.org/10.32503/jmk.v6i2.1516 \\
Sejarah Artikel & $:$ & Artikel diterima (15 April 2021); direvisi (29 April 2021); \\
& disetujui (15 Mei 2021) \\
Email & $:$ & gitamaharani899@gmail.com \\
\hline
\end{tabular}




\section{Pendahuluan}

Masyarakat dunia tengah menghadapi era revolusi industri 4.0. Perubahan terhadap cara manusia memperoduksi barang terjadi di era ini. Pada era ini, produksi barang memanfaatkan teknologi dan mesin. Dengan perubahan dan perkembangan pesat yang terjadi, maka kualitas akan sumber daya manusia (SDM) sangat diutamakan untuk memanfaatkan perubahan dan perkembangan ini untuk kemajuan negara dan perusahaan di dalamnya. Fenomena yang terjadi saat ini adalah, masih tertinggalnya kualitas SDM di Indonesia. Hal ini dibuktikan oleh hasil Indeks Inovasi Global yang merupakan indeks acuan dalam menilai kualitas SDM hampir di seluruh negara. Pada tahun 2018-2020 Indonesia stagnan di peringkat 85 dari 129 negara yang dinilai. Berikut peringkat Indonesia dari tahun ke tahun:

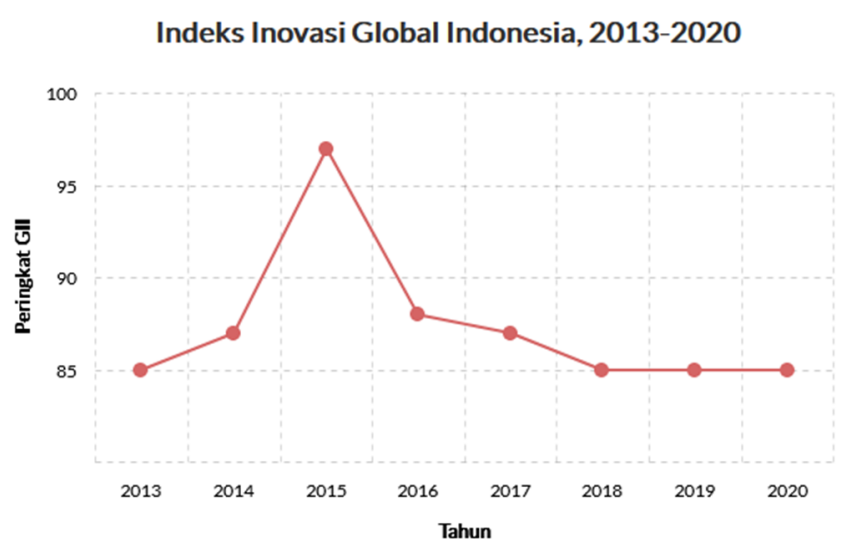

Gambar 1. Indeks Inovasi Global

Sumber: data diolah (Januari 2021)

Dapat dilihat bahwa peringkat Indonesia stagnan di posisi 85 dan di ASEAN, Indonesia berada di posisi kedua terendah. Rendahnya dan stagnannya peringkat Indonesia 3 tahun terakhir di Indeks Inovasi Global salah satunya dipengaruhi oleh faktor pendidikan yang belum maksimal dan alokasi dana untuk research and development masih kecil sehingga penelitian dan pengembangan di Indonesia masih sedikit. Di negara lain yang memiliki SDM berkualitas, mereka mampu menciptakan berbagai inovasi dengan cara memanfaatkan perkembangan teknologi sebagai wujud dari kesiapan dalam memanfaatkan revolusi ini. Sumber daya manusia Indonesia dinilai belum siap untuk mendalami pengetahuan teknologi dan mewujudkan pengetahuan tersebut untuk mendorong perkembangan industri. Fenomena ini cukup memprihatinkan, oleh karena itu penting bagi sebuah negara terutama organisasi di dalamnya untuk mengelola dan mengembangkan kualitas sumber daya manusianya.

Pada sebuah organisasi, dibutuhkannya perwujudan dari aktivitas manajemen yang tepat untuk mengelola sumber daya milik organisasi termasuk di dalamnya pengelolaan akan SDM. Manajemen merupakan aktivitas yang dilakukan organisasi meliputi kegiatan perencanaan, pengorganisasian, pelaksanaan serta pengawasan akan sumber daya untuk mencapai tujuan organisasi (Nurdiansyah \& Rahman, 2019). Dalam aktvitas manajemen, pemanfaatan akan SDM yang dimiliki organisasi merupakan hal yang diprioritaskan. Hal ini dikarenakan SDM 
merupakan aset terpenting organisasi yang akan mengelola seluruh sumber daya organisasi. Itulah alasan penting bagi perusahaan untuk mengelola kualitas SDM yang dimiliki dan dapat terciptanya SDM yang handal serta kompeten agar organisasi mampu menghadapi berbagai perubahan serta perkembangan yang terjadi dan tetap mampu bersaing di industrinya.

Untuk mengelola kualitas SDM, maka dibutuhkannya manajemen sumber daya manusia (MSDM). Wibowo menyatakan MSDM memiliki tujuan untuk perbaikan terhadap peran produktif anggota terhadap organisasi (Wibowo, 2017). Dengan kata lain, MSDM bertujuan untuk menjaga kinerja karyawan. Suryani menyatakan bahwa kinerja karyawan (employee performance) merupakan kinerja yang bersifat individual atas hasil kerja yang diberikan kepada organisasi tempatnya bekerja sehingga setiap karyawan mempunyai hasil kerja yang berbeda satu dengan lainnya dalam menyelesaikan tugas dan tanggung jawabnya (Suryani, dkk., 2020). Kuantitas dalam hal ini berkaitan dengan jumlah hasil pekerjaan karyawan, sementara kualitas merupakan hasil kerja sesuai dengan standar capaian yang ditentukan perusahaan. Dengan hasil kerja yang sesuai harapan, maka dapat dikatakan bahwa kinerja karyawan baik.

Indikator pengukuran kinerja yaitu kualitas serta kuantitas hasil kerja, ketelitian, kreativitas, tanggung jawab, dan inisiatif (Supriyadi \& Sarino, 2019). Dalam membangun kinerja karyawan diperlukan dasar atau fondasi yang kuat untuk bertahan di tengah perubahan dan persaingan bisnis yang kompetitif, maka dibutuhkan strategi dalam menjaga dan meningkatkan kinerja karyawan. Tinggi rendahnya kinerja karyawan di suatu perusahaan bisa dijadikan ukuran terhadap efisiensi dan efektivitas di suatu perusahaan. Kinerja karyawan dapat dipengaruhi oleh berbagai faktor. Rialmi menyatakan bahwa kinerja salah satunya dipengaruhi oleh faktor individu dan faktor sistem (Rialmi, 2017). Faktor individu berupa pengetahuan, keahlian dan keterampilan karyawan yang bisa didapati melalui pelatihan kerja. Faktor sistem yaitu sistem kerja yang dijaga melalui penilaian kinerja. Dengan penilaian kinerja maka kinerja karyawan tidak keluar atau tidak melenceng dari sistem yang telah ditetapkan oleh perusahaan

Di tengah perkembangan pesat di segala bidang mampu menimbulkan kesenjangan terhadap pengetahuan dan keterampilan karyawan karena ragam pekerjaan yang akan dibebankan kepada karyawan semakin variatif. Untuk menghilangkan kesenjangan terserbut dapat melalui pelatihan kerja (job training). Pelatihan adalah suatu aktivitas pendidikan dalam waktu singkat dengan metode yang tersusun sistematis agar karyawan dapat mempelajari pengetahuan tentang teknik pengerjaan dan berbagai keahlian sesuai dengan tujuan pelatihan (Marjaya \& Pasaribu, 2019). Indikator pelatihan melalui kebutuhan pelatihan, tujuan pelatihan berupa perbaharuan pengetahuan (knowledge), sikap (attitude) dan keterampilan (skill) karyawan, metode pelatihan serta evaluasi (Supriatna \& Sutrisna, 2016). Pelatihan dilaksanakan dengan harapan karyawan dapat terlatih dengan professional untuk melaksanakan pekerjaan saat ini di bidang masingmasing sehingga dapat memaksimalkan kontribusinya kepada perusahaan.

Dalam suatu perusahaan penting adanya suatu sistem yang dapat mengevaluasi hasil kerja dan mengukur sejauh mana karyawan sudah berkontribusi untuk perusahaan yang disebut dengan penilaian kinerja (performance appraisal). Penilaian kinerja yaitu evaluasi mengenai hasil kualitas kerja karyawan beserta 
evaluasi mengenai keahlian serta pertumbuhan karyawan dalam bekerja dan melakukan analisis terhadap kinerja karyawan pada suatu periode (Suryani, dkk., 2020). Penilaian kinerja karyawan dapat diukur melalui indikator sikap kerja, biaya, pelayanan dan penyelesaian pekerjaan (Suryani, dkk., 2020). Hasil dari penilaian dijadikan landasan perbaikan terhadap hasil kerja karyawan agar memenuhi capaian standar. Dicapainya standar yang ditetapkan menunjukan bahwa karyawan memiliki kinerja yang baik.

Apabila kinerja karyawan baik, maka dapat dikatakan bahwa karyawan mampu berkontribusi untuk mencapai tujuan perusahaan. Seluruh perusahaan di bidang apapun pasti mengharapkan kinerja karyawan yang maksimal, tidak terkecuali BPJS Ketenagakerjaan yang merupakan lembaga jaminan sosial. Badan Penyelenggara Jaminan Sosial (BPJS) Ketenagakerjaan yaitu lembaga yang menyediakan proteksi terhadap tenaga kerja di Indonesia dalam risiko sosial, ekonomi, dan kematian. Sistem penyelenggaraannya melalui sistem asuransi sosial. Permasalahan yang dihadapi BPJS Ketenagakerjaan yaitu terjadinya defisit pada program jaminan hari tua serta jaminan pensiun yang dimulai pada tahun 2019 dan puncaknya pada tahun 2020 yang jumlahnya mencapai puluhan triliun. Lalu, pada tahun 2020 jumlah kepesertaan BPJS Ketenagakerjaan berkurang dan banyaknya laporan mengenai iuran kepesertaan yang macet. Berbagai masalah ini menunjukan adanya penurunan terhadap kinerja BPJS Ketenagakerjaan.

Untuk memfokuskan penelitian, dilakukan penelitian pada Direktorat Umum dan SDM BPJS Ketenagakerjaan Pusat yang terdiri dari 4 Deputi Direktur, antara lain; Deputi Direktur Bidang Human Capital, Bidang Learning, Bidang Pengadaan dan Bidang Pengelolaan Aset dan Layanan Umum. Direktorat Umum dan SDM berperan untuk melakukan pengelolaan terhadap seluruh karyawan sehingga kinerja, kualitas, dan kebutuhan seluruh karyawan terjaga dan terpenuhi dengan baik. Sebagai Direktorat yang memiliki peran utama dalam mengelola karyawan, maka kinerja karyawan Direktorat Umum dan SDM sangat penting untuk diperhatikan. Dengan kinerja yang baik maka hal ini menandakan bahwa mereka mampu menjalani fungsi dan tugasnya yaitu mengelola kualitas dan kebutuhan seluruh karyawan BPJS Ketenagakerjaan Pusat.

Namun, kinerja karyawan Direktorat Umum dan SDM belum optimal diduga dikarenakan oleh pelatihan kerja dan penilaian kinerja. BPJS Ketenagakerjaan hanya menyelenggarakan pelatihan berupa orientasi persiapan kerja (OPK) dan pelatihan untuk kenaikan jabatan sehingga tidak adanya pelatihan untuk pembaharuan terhadap pengetahuan dan keterampilan karyawan. Di tengah perkembangan dan perubahan yang pesat, pekerjaan karyawan semakin beragam. Apabila karyawan tidak dibekali dengan pembaharuan pengetahuan dan keterampilan untuk menjalani pekerjaan saat ini, maka dapat mengakibatkan hasil dari kerja karyawan yang tidak mencapai standar perusahaan. Selain itu, masih kurang efektifnya hasil dari pelaksanaan penilaian kinerja untuk memperbaiki kinerja karyawan.

Berangkat dari uraian di atas, disimpulkan bahwa kinerja karyawan merupakan kunci utama dalam perkembangan perusahaan. Oleh karena itu dibutuhkannya karyawan yang berkualitas. Dengan pengelolaan karyawan yang tepat di perusahaan, maka perusahaan dapat merasakan manfaatnya yaitu meningkatnya produktivitas perusahaan. Hal ini dikarenakan apabila karyawan 
berkualitas maka dapat tercapainya target dan tujuan perusahaan sehingga produktivitas perusahaan meningkat (Kristanti \& Pangastuti, 2019). Apabila produktivitas perusahaan meningkat maka keuntungan perusahaan akan meningkat dan perusahaan mampu terus bersaing di industrinya dengan mengikuti segala perkembangan yang terjadi.

Pada penelitian sebelumnya oleh Jumawan \& Mora (Jumawan \& Mora, 2018) menunjukan pelatihan berpengaruh positif signifikan pada kinerja karyawan. Tetapi, penelitian oleh Ningsi, dkk. (Ningsi, dkk., 2016) menunjukan pelatihan kerja berpengaruh positif tidak signifikan pada kinerja karyawan. Penelitian sebelumnya mengenai penilaian kinerja oleh Ulfa \& Kasmiruddin (Ulfa \& Kasmiruddin, 2018) menunjukan penilaian kinerja berpengaruh positif signifikan pada kinerja karyawan. Tetapi dalam penelitian oleh Agustin (Agustin, 2019) menunjukan penilaian kinerja berpengaruh positif tidak signifikan pada kinerja karyawan. Dari berbagai penelitian yang telah dilakukan yang sejalan dengan tema penelitian ini ditemukannya research gap. Terdapat penelitian yang menunjukan pelatihan kerja berpengaruh positif tidak signifikan pada kinerja karyawan karena semakin baik pelatihan belum menjamin akan meningkatnya kinerja karyawan. Penelitian lain menunjukan penilaian kinerja berpengaruh positif tidak signifikan pada kinerja karyawan karena dengan hanya penilaian saja maka karyawan tidak bisa langsung meningkatkan kinerjanya dan dibutuhkannya faktor dorongan lain.

Berdasarkan fenomena yang terjadi dan terdapat research gap pada penelitian sebelumnya, maka dalam penelitian ini akan membahas lebih dalam mengenai pengaruh pelatihan kerja dan penilaian kinerja terhadap kinerja karyawan dengan metode yang berbeda dari penelitian-penelitian sebelumnya yaitu dengan teknik analisis inferensial. Penelitian ini bertujuan untuk mengetahui dan membuktikan mengenai pengaruh pelatihan kerja terhadap kinerja karyawan, pengaruh penilaian kinerja terhadap kinerja karyawan, dan pengaruh pelatihan kerja dan penilaian kinerja secara bersama-sama terhadap kinerja karyawan Direktorat Umum dan SDM BPJS Ketenagakerjaan Pusat. Penelitian ini penting untuk dilakukan demi menjaga kinerja karyawan BPJS Ketenagakerjaan sehingga kinerja karyawan dapat memenuhi harapan perusahaan dan memaksimalkan fungsi serta tugas Direktorat Umum dan SDM.

\section{Metode Penelitian}

Direktorat Umum dan SDM BPJS Ketenagakerjaan Pusat yang terletak di Jakarta Selatan Indonesia merupakan tempat dilaksanakannya penelitian ini. Penelitian dilakukan bulan Oktober 2020 hingga bulan Januari 2021. Metode penelitian yang digunakan yaitu pendekatan kuanitatif dimana hasil penelitian disimpulkan berdasarkan data berbentuk angka mengenai objek yang sedang diteliti. Variabel yang diteliti antara lain pelatihan kerja sebagai $X_{1}$, penilaian kinerja sebagai $X_{2}$, serta kinerja karyawan sebagai Y. Dari variabel yang diteliti dan tujuan dari dilakukannya penelitian ini, maka kerangka berpikir yang disusun sebagai berikut: 


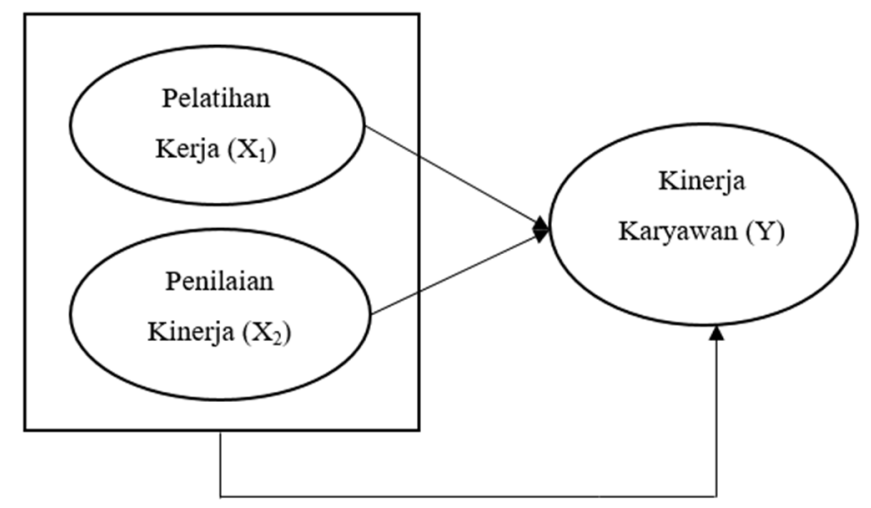

Gambar 2. Kerangka Berpikir

Adapun populasi penelitian sebesar 100 karyawan dan menggunakan sampel jenuh. Sumber data primer dengan teknik mengumpulkan data melalui kuesioner dan data sekunder melalui buku dan jurnal digunakan untuk menyusun penelitian ini. Dikarenakan penelitian dilaksanakan selama pandemi, maka kuesioner didistribusikan melalui google form. Kuesioner merupakan teknik untuk mengumpulkan informasi dengan memberikan daftar pernyataan atau pertanyaan kepada subyek penelitian (Damayanti, 2014). Jenis kuesioner yang digunakan yaitu berupa kuesioner tertutup dimana daftar pertanyaan atau pernyataan sudah disertai pilihan jawaban. Skala likert digunakan dalam kuesioner dengan nilai 1-5 dimana responden menjawab pernyataan yang disediakan dengan pilihan dari sangat tidak setuju-sangat setuju. Berbagai teknik analisis data digunakan, dimulai dari statistik deskriptif yang bertujuan mendeskripsi suatu data yang berhubungan dengan keadaan atau fenomena sehingga lebih mudah dipahami (Nasution, 2017). Hasil uji ini biasanya terdiri dari rata-rata, jumlah, ragam data, dan lainnya.

Dalam melakukan statistik deskriptif dibutuhkan penentuan panjang kelas interval untuk mengkategorikan intervalnya dengan perhitungan (nilai tertingginilai terendah)/jumlah kelas sesuai pada skala likert dan didapati panjang kelasnya 0,8 (Sugiyono, 2016). Penelitian ini menggunakan mean atau rata-rata untuk mengukur jawaban subyek penelitian pada tiap variabel. Sebagai persyaratan analisis kualitas data, dilakukan uji inferensial yang terdiri dari uji validitas bertujuan memastikan alat ukur valid atau sahih dan uji reliabilitas juga digunakan untuk mengetahui konsistensi instrumen penelitian (Yusup, 2018). Adapun ketentuan instrumen dinyatakan valid yaitu apabila $r_{\text {hitung }}>r_{\text {tabel }}$ (Gunawan, 2018).

Untuk uji hipotesis, terdapat uji $\mathrm{T}$ bertujuan untuk membuktikan pengaruh $\mathrm{X}_{1}$ dan $\mathrm{X}_{2}$ secara parsial pada $\mathrm{Y}$ dan uji $\mathrm{F}$ bermaksud membuktikan pengaruh $\mathrm{X}_{1}$ dan $X_{2}$ secara simultan pada $Y$ (Hendri \& Setiawan, 2017). Landasan keputusan uji $\mathrm{T}$ yaitu dilakukan perbandingan nilai $t_{\text {hitung }}$ dengan $t_{\text {tabel }}$ dan pada uji $\mathrm{F}$ juga dilakukan perbandingan $\mathrm{f}_{\text {hitung }}$ dengan $\mathrm{f}_{\text {tabel }}$. Selanjutnya terdapat uji (uji $\mathrm{R}^{2}$ ) untuk mengetahui besar pengaruh $\mathrm{X}$ dalam mempengaruhi $\mathrm{Y}$. Jika nilai $\mathrm{R}^{2} \mathrm{X}$ besar, maka semakin besar juga pengaruhnya terhadap perubahan $\mathrm{Y}$ dan berlaku sebaliknya (Kurniawan, 2019). 


\section{Hasil dan Pembahasan}

\section{Hasil}

Subyek penelitian dikelompokan dalam 3 kategori karakteristik, antara lain berdasarkan jenis kelamin, usia dan masa kerja. Dari jumlah 100 responden, banyak responden laki-laki 61 dan perempuan sebanyak 39. Berdasarkan umur, usia 26-30 tahun terdiri dari 28 responden, usia $>40$ tahun sebanyak 27 responden, dan usia 31-35 tahun berjumlah 26 responden dan usia 36-40 tahun sebanyak 19 responden. Terdapatnya responden dari berbagai kalangan usia dan jumlahnya cukup rata, menunjukan bahwa perusahaan melakukan program rekrutmen secara berkala dan konsisten. Hal ini pertanda baik karena perusahaan berarti terus mencari caloncalon karyawan yang berkualitas sesuai dengan kualifikasi perusahaan yang mampu membantu perusahaan berkembang.

Berdasarkan masa kerja didominasi masa kerja $>6$ tahun sebanyak 47, lalu 4-6 tahun sebanyak 29 dan 1-3 tahun sebanyak 24. Banyaknya responden dengan masa kerja di atas 6 tahun menunjukan bahwa adanya loyalitas pada diri responden terhadap perusahaan. Berdasarkan analisis statistik deskriptif, hasil rata-rata pada variabel pelatihan kerja $\left(\mathrm{X}_{1}\right)$ yaitu sebesar 4,44 yang berarti responden "sangat setuju" dengan pernyataan pada variabel pelatihan kerja.

Lalu, hasil rata-rata pada variabel penilaian kinerja $\left(\mathrm{X}_{2}\right)$ sebesar 4,28 yang memiliki arti responden "sangat setuju" dengan pernyataan pada variabel penilaian kinerja dan hasil rata-rata pada variabel kinerja (Y) yaitu 4,25 yang berarti responden "sangat setuju" dengan pernyataan pada variabel kinerja karyawan. Selanjutnya uji validitas dilakukan dengan bantuan software SPSS Statistics 23 dengan rumus korelasi Pearson Product Moment. Uji ini dilakukan kepada 30 responden pertama yang berarti df (degree of freedom) yaitu 30 dengan sig 5\%. Dengan df sebesar 30 dan tingkat signifikan 0,05, didapati nilai $r_{\text {tabel }} 0,374$ yang akan digunakan untuk dibandingkan dengan rhitung. Berikut hasil uji validitas:

Tabel 1. Hasil Uji Validitas

\begin{tabular}{cccccc}
\hline Item & $\mathrm{r}_{\text {hitung }}$ & Item & $\mathrm{r}_{\text {hitung }}$ & $\mathrm{r}_{\text {tabel }}$ & Keterangan \\
\hline 1 & 0,657 & 16 & 0,800 & 0,374 & Valid \\
\hline 2 & 0,712 & 17 & 0,835 & 0,374 & Valid \\
\hline 3 & 0,757 & 18 & 0,700 & 0,374 & Valid \\
\hline 4 & 0,626 & 19 & 0,649 & 0,374 & Valid \\
\hline 5 & 0,637 & 20 & 0,717 & 0,374 & Valid \\
\hline 6 & 0,671 & 21 & 0,777 & 0,374 & Valid \\
\hline 7 & 0,535 & 22 & 0,758 & 0,374 & Valid \\
\hline 8 & 0,714 & 23 & 0,636 & 0,374 & Valid \\
\hline 9 & 0,735 & 24 & 0,683 & 0,374 & Valid \\
\hline 10 & 0,585 & 25 & 0,779 & 0,374 & Valid \\
\hline 11 & 0,582 & 26 & 0,626 & 0,374 & Valid \\
\hline 12 & 0,462 & 27 & 0,764 & 0,374 & Valid \\
\hline 13 & 0,583 & 28 & 0,636 & 0,374 & Valid \\
\hline 14 & 0,769 & 29 & 0,757 & 0,374 & Valid \\
\hline 15 & 0,812 & 30 & 0,848 & 0,374 & Valid
\end{tabular}


Sumber: data diolah (Januari 2021)

Tabel 1 menunjukan $r_{\text {hitung }}$ seluruh item pernyataan $>0,374$. Maka seluruh pernyataan dinyatakan valid dan layak untuk mengukur masing-masing variabel karena $r_{\text {hitung }}>\mathrm{r}_{\text {tabel. }}$. Uji reliabilitas juga dilakukan untuk menguji kualitas data dengan rumus Alpha Cronbach pada 30 responden pertama dengan bantuan software SPSS Statistics 23. Instrumen dinyatakan reliabel jika nilai Alpha Cronbach $>0,60$. Berikut hasil uji reliabilitas:

Tabel 2. Hasil Uji Reliabilitas

\begin{tabular}{ccc}
\hline Model & $\begin{array}{c}\text { Cronbach's } \\
\text { Alpha }\end{array}$ & $\begin{array}{c}\text { Nof } \\
\text { Items }\end{array}$ \\
\hline Kinerja karyawan & 0,862 & 12 \\
\hline Pelatihan kerja & 0,906 & 10 \\
\hline Penilaian kinerja & 0,863 & 8 \\
\hline
\end{tabular}

Sumber: data diolah (Januari 2021)

Pada tabel 2, diketahui nilai Alpha Cronbach pada variabel kinerja karyawan sebesar 0,862 , pelatihan kerja sebesar 0,906 , dan penilaian kinerja sebesar 0,863. Maka, seluruh instrumen pernyataan dari 3 variabel reliabel dan bisa dilanjutkan untuk mengukur variabel tersebut. Untuk seluruh uji hipotesis perhitungannya juga menggunakan bantuan software SPSS Statistics 23. Pada uji signifikan parsial (uji $\mathrm{T}$ ) dihitung terlebih dahulu $\mathrm{t}_{\text {tabel }}$ dengan perhitungan $\mathrm{t}(\mathrm{a} / 2$ :nk-1) $($ Priyatna, 2020), a = 0,05, $\mathrm{n}($ responden $)=100$, dan $\mathrm{k}($ jumlah $\mathrm{X})=2$. Maka, didapati nilai $\mathrm{t}_{\text {tabel }} 1,984$. Berikut hasil uji $\mathrm{T}$ :

Tabel 3. Hasil Uji $T$ Variabel $X_{1}$ dan $X_{2}$ Terhadap $Y$

\begin{tabular}{ccc}
\hline Model & $\mathrm{t}$ & Sig \\
\hline Pelatihan Kerja & 4.687 & .000 \\
\hline Penilaian Kinerja & 4.543 & .000
\end{tabular}

Sumber: data diolah (Januari 2021)

Pada tabel 3 terdapat nilai thitung pelatihan kerja sebesar 4,687, maka thitung 4,687 > dari nilai $t_{\text {tabel }} 1,984$. Selain itu, nilai $t_{\text {hitung }}$ penilaian kinerja sebesar 4,543, maka thitung 4,543> dari nilai $t_{\text {tabel }} 1$ 1,884. Maka, $X_{1}$ dan $X_{2}$ secara parsial berpengaruh pada $Y$. Selanjutnya dilakukan uji $F$ untuk dengan menentukan $\mathrm{f}_{\text {tabel }}$ dengan rumus $\mathrm{f}(\mathrm{k}: \mathrm{n}-\mathrm{k})$ (Priyatna, 2020) dengan $\mathrm{n}$ sebesar 100 dan $\mathrm{k}$ yaitu 2, maka nilai $\mathrm{f}_{\text {tabel }}$ sebesar 3,09. Berikut hasil uji F:

Tabel 4. Hasil Uji F Variabel X Terhadap Y

\begin{tabular}{ccl} 
Model & F & Sig. \\
\hline Regression & 53.460 & $.000^{\mathrm{b}}$
\end{tabular}

Sumber: data diolah (Januari 2021) 
Pada tabel 4, nilai $f_{\text {hitung }}$ sebesar 53,46, maka $f_{\text {hitung }} 53,46>$ dari 3,09 yang merupakan nilai $\mathrm{f}_{\text {tabel. }}$ Maka, pelatihan kerja dan penilaian kinerja berpengaruh secara simultan terhadap kinerja karyawan. Setelah membuktikan pengaruh secara simultan, selanjutnya dilakukan uji $\left(\mathrm{R}^{2}\right)$ menggunakan SPSS Statistics 23 , berikut hasil uji $\mathrm{R}^{2}$ :

Tabel 5. Hasil Uji $R^{2}$ Variabel $X_{1}$ dan $X_{2}$ Terhadap $Y$

\begin{tabular}{ccc}
\hline Model & $\mathrm{R}$ & $R^{2}$ \\
\hline 1. Pelatihan kerja & $.650^{\mathrm{a}}$ & .423 \\
\hline 2. Penilaian kinerja & $.645 \mathrm{a}$ & .417 \\
\hline
\end{tabular}

Sumber: data diolah (Januari 2021)

Pada tabel 5, nilai $\mathrm{R}^{2}$ pelatihan kerja sebesar 0,423. Maka, pelatihan kerja mempengaruhi kinerja karyawan sebesar $42,3 \%$ dan dapat dinyatakan pelatihan kerja cukup besar mempengaruhi kinerja karyawan. Selain itu, nilai $\mathrm{R}^{2}$ penilaian kinerja sebesar 0,417. Maka penilaian kinerja mempengaruhi kinerja karyawan sebesar $41,7 \%$ dan dapat dikatakan penilaian kinerja mempengaruhi kinerja karyawan cukup besar.

\section{Pembahasan}

Berdasarkan hasil uji $\mathrm{T}$, hasilnya memenuhi persyaratan untuk dinyatakan pelatihan kerja memiliki pengaruh pada kinerja karyawan Direktorat Umum dan SDM BPJS Ketenagakerjaan Pusat. Dari hasil uji $\mathrm{R}^{2}$ diketahui bahwa $\mathrm{X}_{1}$ memiliki pengaruh cukup besar terhadap Y yaitu sebesar $42,3 \%$. Pelatihan kerja terbukti berpengaruh terhadap kinerja karyawan sejalan dengan teori yang diungkapkan oleh Masram \& Mu'ah bahwa dengan diadakannya pelatihan kerja mampu memberikan keahlian, konsep ataupun sikap untuk meningkatkan kinerja karyawan di perusahaan (Masram \& Mu'ah, 2017). Pelatihan kerja dapat menghilangkan kesenjangan pengetahuan dan keterampilan pada diri karyawan sehingga karyawan mampu menyelesaikan hasil kerjanya sesuai dengan capaian standar. Dengan pelatihan, kebutuhan karyawan untuk berkembang dapat terpenuhi dan persiapan untuk promosi jabatan juga terpenuhi.

Hasil penelitian ini mendukung penelitian Jumawan \& Mora (Jumawan \& Mora, 2018) dan penelitian oleh Afroz (Afroz, 2018) yang menyatakan pelatihan kerja berpengaruh pada kinerja karyawan. Pelatihan dapat mengajarkan dan memberikan pengalaman untuk menyelesaikan pekerjaan kepada karyawan sehingga proses penyelesaian pekerjaan memenuhi standar. Dengan adanya pelatihan kerja maka dapat membawa manfaat bagi karyawan dan perusahaan. Apabila perusahaan memberikan pelatihan kerja, maka karyawan siap untuk menghadapi berbagai perubahan yang terjadi sehingga dapat dimanfaatkan untuk kemajuan perusahaan. Selain itu, pelatihan juga merupakan wujud pemenuhan kebutuhan akan pengembangan karyawan sehingga dapat menumbuhkan rasa loyal karyawan pada perusahaan sehingga dapat dipertahankannya karyawan yang berkualitas dan dibutuhkan oleh perusahaan.

Jika karyawan Direktorat Umum dan SDM BPJS Ketenagakerjaan Pusat menguasai pengetahuan serta keterampilan yang dibutuhkan dalam menyelesaikan 
pekerjaan, maka karyawan dapat memberikan pelayanan yang maksimal dan mampu menjalankan perannya untuk mengelola kualitas dan kebutuhan seluruh karyawan BPJS Ketenagakerjaan Pusat. Perubahan teknologi dalam hal pelayanan bisa membawa dampak baik dan buruk, maka perusahaan harus mempersiapkan karyawannya agar perubahan ini dapat membawa dampak baik bukan dampak buruk. Pelatihan juga merupakan upaya dalam mengurangi resiko kecelakaan kerja, dan meningkatkan keahlian manajerial karyawan (Wibowo, 2017).

Selain itu, dengan adanya pelatihan maka karyawan memiliki bekal untuk membantu perusahaan bersaing di industrinya. Dalam pelatihan terdapat berbagai metode pelatihan, contohnya pelatihan di tempat kerja (on the job training), simulasi, pelatihan melalui peralatan audio visual, dan pelatihan di luar kerja (off the job training) (Wibowo, 2017). Metode pelatihan yang dipakai disesuaikan dengan tujuan capaian dan kebutuhan karyawan. Diharapkan dengan adanya pelatihan dapat memberikan pengalaman mengenai penyelesaian kerja sehingga karyawan bisa mempraktekannya langsung secara professional dalam proses penyelesaian kerjanya.

Lalu, pada hasil uji $\mathrm{T}$ juga diketahui bahwa penilaian kinerja berpengaruh pada kinerja karyawan Direktorat Umum dan SDM BPJS Ketenagakerjaan Pusat. Dari hasil uji $\mathrm{R}^{2}$ diketahui penilaian kinerja berpengaruh sebesar $41,7 \%$ pada kinerja karyawan yang dikatakan cukup besar mempengaruhi. Penilaian kinerja terbukti berpengaruh terhadap kinerja karyawan sejalan dengan teori yang diungkapkan oleh Segoro bahwa dengan adanya penilaian kinerja maka adanya suatu sistem untuk menilai kinerja karyawan sehingga karyawan akan bertanggung jawab untuk menyelesaikan pekerjaanya sesuai dengan standar perusahaan (Segoro, 2018). Dengan dilaksanakannya penilaian kinerja maka karyawan Direktorat Umum dan SDM BPJS Ketenagakerjaan Pusat dapat mengetahui kekuatan dan kelemahannya dalam menyelesaikan pekerjaannya sehingga karyawan dapat memperbaiki hasil kerjanya.

Hasil penelitian ini mendukung penelitian Ulfa \& Kasmiruddin (Ulfa \& Kasmiruddin, 2018) dan Girma, et al. (Girma. et al., 2016) bahwa penilaian kinerja berpengaruh pada kinerja karyawan. Hal yang harus diperhatikan dalam menjalani penilaian kinerja adalah harus adanya keterkaitan antara standar kinerja dengan tujuan perusahaan sehingga unsur-unsur yang dinilai tepat. Selain itu, hasil penilaian kinerja juga harus bisa membedakan karyawan yang produktif dan tidak, serta bisa dimengerti dan digunakan oleh pihak-pihak yang berwenang seperti manajer dan pemimpin perusahaan untuk mengambil sebuah keputusan (Setiobudi, 2017). Penilaian kinerja yang baik dilakukan secara formal, konsisten dan manfaat dari hasil penilaian bisa dirasakan baik bagi karyawan maupun perusahaan.

Hasil dari penilaian kinerja juga dijadikan dasar keputusan yang bersifat kepegawaian seperti pemberian insentif, kenaikan gaji, promosi jabatan hingga pemutusan hubungan kerja. Salah satu tujuan penting dari dilaksanakannya penilaian yaitu untuk memperlancar komunikasi antara karyawan dan perusahaan. Dengan ini, penilaian kinerja harus dilaksanakan oleh seseorang yang ahli di bidangnya dan mampu bersikap netral dalam penilaian. Umumnya penilaian kinerja menggunakan key performance indikator (KPI) seperti yang sudah dilakukan di BPJS Ketenagakerjaan sebagai upaya agar penilaian kinerja tepat. Penggunaan KPI bertujuan agar penilaian kinerja lebih tepat dan terukur sesuai dengan harapan 
perusahaan. KPI disesuaikan dan dispesifikan pada tiap departemen karyawan sehingga yang dinilai sesuai dengan peran karyawan masing-masing.

Penilaian kinerja memegang peranan penting dalam memperbaiki kinerja karyawan, maka pelaksanaannya harus dilaksanakan dengan konsisten sehingga dapat diketahui pertumbuhan kinerja tiap karyawan tiap waktu. Periode pelaksanaan penilaian kinerja disesuaikan dengan kebijakan perusahaan. Jangka waktu penilaian beragam, mulai dari 1x selama 3 bulan, 1x selama 6 bulan, dan 12x selama 1 tahun. Metode penilaian terdiri dari metode penilaian umpan balik 360 derajat, esai, peringkat, dan standar kerja (Fathoroni, dkk., 2020). Apapun metode penilaian yang digunakan diharapkan tujuan penting dari dilaksanakannya penilaian tetap tercapai yaitu untuk memperlancar komunikasi antara karyawan dan perusahaan serta mengetahui perkembangan kinerja tiap karyawan.

Berangkat dari hasil uji $\mathrm{F}$, maka dapat dinyatakan pelatihan kerja dan penilaian kinerja secara simultan memiliki pengaruh pada kinerja karyawan Direktorat Umum dan SDM BPJS Ketenagakerjaan Pusat. Dengan hasil uji ini, maka perusahaan harus memperhatikan proses pelaksanaan dari dua hal tersebut untuk meningkatkan kinerja karyawannya. Sebagai lembaga yang berkontribusi dalam meningkatkan kesejahteraan tenaga kerja di Indonesia, maka BPJS Ketenagakerjaan harus menjaga dan mengelola kinerja karyawannya sehingga perusahaan dapat memberikan pelayanan yang terbaik dan mewujudkan visi misi perusahaan.

Kebutuhan akan pelatihan karyawan dapat dilakukan dengan analisis kebutuhan training atau training need analysis (TNA) dimana analisis ini untuk mengidentifikasi potensi dan kebutuhan tiap karyawan sesuai dengan kemampuannya, minat karyawan dan tujuan yang hendak dicapai. Selain itu, untuk mengetahui hasil kinerja karyawan sesuai dengan keadaan sebenarnya maka perusahaan harus melaksanakan proses penilaian kinerja dengan konsisten, transparan dan adil. Dengan ini bisa menumbuhkan rasa bahwa penilaian itu penting sehingga karyawan menjalani penilaian dengan jujur dan karyawan dapat menghargai serta menerima hasil penilaian. Jangan sampai ada intervensi oleh pihak luar terhadap hasil penilaian kinerja sehingga terjadinya ketidakadilan hingga bias dalam melakukan penilaian. Apabila hal ini terjadi maka pelaksanaan penilaian akan sia-sia karena keputusan dari hasil penilaian tidak akan tepat sasaran.

Pelaksanaan penilaian harus dirasakan manfaatnya baik perusahaan maupun karyawan. Perusahaan mengharapkan dengan adanya penilaian maka dapat diketahui sejauh mana karyawan berkontribusi untuk perusahaan dan sebagai pertimbangan untuk berbagai keputusan. Bagi karyawan, penilaian penting untuk perbaikan kerja kedepannya sehingga karyawan dapat memenuhi standar kerja. Agar perusahaan bisa terus bersaing di industrinya, maka kinerja karyawan adalah kunci utama yang harus selalu diperhatikan. Jangan sampai kinerja karyawan menurun sehingga tidak terlaksananya fungsi dan tugas karyawan. Jika hal ini terjadi dalam jangka panjang, berpotensi besar dapat menurunkan produktivitas perusahaan. 


\section{Simpulan}

Berdasarkan berbagai uji yang telah dilaksanakan, maka kesimpulan penelitian ini yaitu; pelatihan kerja berpengaruh terhadap kinerja karyawan Direktorat Umum dan SDM BPJS Ketenagakerjaan Pusat, penilaian kinerja berpengaruh terhadap kinerja karyawan Direktorat Umum dan SDM BPJS Ketenagakerjaan Pusat, pelatihan kerja dan penilaian kinerja secara bersama-sama berpengaruh terhadap kinerja karyawan Direktorat Umum dan SDM BPJS Ketenagakerjaan Pusat.

Hasil penelitian ini diharapkan perusahaan dapat menyadari pentingnya mengadakan pelatihan kerja dan proses penilaian kinerja. Dengan diberikannya pelatihan kerja yang dibutuhkan, maka karyawan mampu merespon tuntutan pekerjaan dengan baik dan hasil kerjanya sesuai dengan harapan perusahaan. Selain itu, proses penilaian kinerja harus dilakukan dengan adil dan jujur. Dengan hasil penilaian kinerja yang sesuai dengan keadaan sebenarnya maka hasil penilaian kinerja ini bisa dijadikan bahan perbaikan terhadap hasil kerja karyawan dan karyawan termotivasi untuk meningkatkan kinerjanya. Dengan dilaksanakannya pelatihan kerja dan penilaian kinerja maka diharapkan dapat terwujudnya karyawan yang berkualitas untuk bersaing di era revolusi.

Dalam penyusunan penelitian ini, peneliti mengalami keterbatasan seperti pada proses pengambilan data, peneliti tidak dapat langsung menemui dan mendampingi responden dari penelitian ini karena penelitian dilaksanakan selama pandemi Covid-19. Keterbatasan ini dapat diatasi oleh peneliti dengan mendistribusikan kuesioner penelitian melalui google form. Selain itu, penelitian ini hanya meneliti pengaruh dua variabel pada kinerja karyawan yaitu pelatihan kerja dan penilaian kinerja. Sedangkan masih banyak variabel lain yang mampu memberikan pengaruh pada kinerja karyawan. Bagi penelitian selanjutnya diharapkan mampu dilakukannya penelitian dengan variabel lain yang mempengaruhi kinerja karyawan sehingga dapat menjadi referensi bagi perusahaan dalam menjaga dan mengelola kinerja karyawannya.

\section{Daftar Pustaka}

Afroz, N. (2018). Effects of Training on Employee Performance: A Study on Banking Sector, Tangail Bangladesh. Global Journal of Economic and Business, 4(1), 111-124. https://doi.org/10.12816/0048158.

Agustin, T. (2019). Pengaruh Penilaian Kinerja Terhadap Kinerja Pegawai Melalui Pengembangan Karir Pegawai Pada Pt. Bang Pembangunan Daerah Kalimantan Barat Cabang Sekadau. Journal of Chemical Information and Modeling, 53(9), 1689-1699. http://dx.doi.org/10.26418/ejme.v7i1.28448.

Damayanti, D. (2014). Sihapes (Sistem Informasi Hasil Penilaian Siswa) Bagi Sekolah Menengah Pertama Di Smp Negeri 7 Semarang. Edu Komputika Journal, 1(2), 52-62. https://doi.org/10.15294/edukomputika.v1i2.7803.

Fathoroni, A., dkk. (2020). Buku Tutorial Sistem Pendukung Keputusan Penilaian

Kinerja Dosen Menggunakan Metode 360 Degree Feedback. Bandung: Kreatif Industri Nusantara.

Girma, T., et al. (2016). The Effect of Performance Appraisal On Employee 
Performance: A Survey On Administrative Staff Of Hawassa Univesity. 18, 36-44. https://doi.org/10.9790/487X-1803023644.

Gunawan, C. (2018). Mahir Menguasai SPSS: (Mudah mengolah Data Dengan IBM SPSS Statistic 25). Yogyakarta: Deepublish.

Hendri, \& Setiawan, R. (2017). Pengaruh Motivasi Kerja dan Kompensasi

Terhadap Kinerja Karyawan Di PT. Samudra Bahari Utama. AGORA, 5(1), $1-8$.

Jumawan, J., \& Mora, M. T. (2018). Pengaruh Pelatihan Dan Pengembangan Karier Terhadap Kinerja Karyawan Perusahaan Korporasi. Jurnal Riset Manajemen Dan Bisnis (JRMB) Fakultas Ekonomi UNIAT, 3(3), 343-352. https://doi.org/10.36226/jrmb.v3i3.153.

Kristanti, D., \& Pangastuti, R. L. (2019). Kiat-Kiat Merangsang Kinerja Karyawan Bagian Produksi. Surabaya: Media Sahabat Cendikia.

Kurniawan, A. (2019). Pengolahan Riset Ekonomi Jadi Mudah Dengan IBM SPSS. Surabaya: Jakad Publishing.

Marjaya, I., \& Pasaribu, F. (2019). Pengaruh Kepemimpinan, Motivasi, Dan Pelatihan Terhadap Kinerja Pegawai. Maneggio: Jurnal Ilmiah Magister Manajemen, 2(1), 129-147. https://doi.org/10.30596/maneggio.v2i1.3650

Masram \& Mu'ah. (2017). Manajemen Sumber Daya Manusia Profesional. Sidoarjo: Zifatama Publisher.

Nasution, L. M. (2017). Statistik Deskriptif. Jurnal Hikmah, 14(1), 49-55. https://doi.org/10.1021/ja01626a006.

Ningsi, C. A., dkk., (2016). Pengaruh Pelatihan dan Promosi Terhadap Motivasi dan Kinerja Karyawan (Studi pada Karyawan PT.PLN (Persero) Area Kendari). Jurnal Ilmiah Ilmu Administrasi Publik, 5(2), 131-143. https://doi.org/10.26858/jiap.v5i2.1765

Nurdiansyah, H., \& Rahman, R. S. (2019). Pengantar Manajemen. Yogyakarta: Diandra Kreatif.

Priyatna, S, E. (2020). Analisis Statistik Sosial Rangkaian Penelitian Kuantitatif Menggunakan SPSS. Banjarmasin: Yayasan Kita Menulis.

Rialmi, Z. (2017). Pengaruh Keadilan Prosedural Yang Diterapkan Kepemimpinan Pegawai Dan Kepuasan Kerja Pegawai Terhadap Kinerja Dari Pegawai BPBD Provinsi Riau. Jurnal Mandiri: Ilmu Pengetahuan, Seni, dan Teknologi. 1(2), 354-374. https://doi.org/10.33753/mandiri.v1i2.26.

Segoro, W. (2018). Buku ajar Manajemen Sumber Daya Manusia. Yogyakarta: Deepublish.

Setiobudi, E. (2017). Analisis Sistem Penilaian Kinerja Karyawan Studi pada PT. Tridharma Kencana. JABE (Journal of Applied Business and Economic), 3(3), 170. https://doi.org/10.30998/jabe.v3i3.1768.

Sugiyono, P. D. (2016). Metode Penelitian Kuantitatif, Kualitatif,dan R\&D. Bandung: Alfabeta.

Supriatna, A., \& Sutisna, M. (2016). Pengaruh Pelatihan Kerja Terhadap Kinerja Karyawan (Studi Kasus Pdam Tirta Bumi Wibawa Kota Sukabumi). Jurnal Riset Bisnis dan Investasi. 2(3), 43-55. https://doi.org/10.35313/jrbi.v2i3.92

Supriyadi, N. Y., \& Sarino, A. (2019). Kunci untuk meningkatkan kinerja. Jurnal Pendidikan Manajemen Perkantoran. 4(1): 55-66. https://doi.org/10.17509/jpm.v4i1.14955. 
Suryani, dkk. (2020). Kinerja Sumber Daya Manusia. Teori, Aplikasi dan Penelitian. Bali: Nilacakra.

Ulfa, A., \& Kasmiruddin. (2018). Pengaruh Penilaian Kinerja dan Reward terhadap Kinerja Karyawan pada PT. Jalur Nugraha Ekakurir Pekanbaru. JOM FISIP. $5(2), 1-10$.

Wibowo. (2017). Manajemen Sumber Daya Manusia (Edisi Revisi). Jakarta: R.A.De.Rozarie.

Yusup, F. (2018). Uji Validitas dan Reliabilitas Instrumen Penelitian Kuantitatif. Jurnal Tarbiyah: Jurnal Ilmiah Kependidikan, 7(1), 17-23. https://doi.org/10.18592/tarbiyah.v7i1.2100. 